Mevlüt AYDOĞMUŞ

Curriculum and Instruction Department, Necmettin Erbakan University

Konya, Turkey

Original scientific paper

Hüseyin SERÇE ${ }^{2}$

UDC: 371.15

Curriculum and Instruction Department, Selçuk University

Konya, Turkey

\title{
INVESTIGATION OF REGULATORY ROLE OF COLLECTIVE TEACHER EFFICACY IN THE EFFECT OF JOB SATISFACTION AND SATISFACTION WITH LIFE ON PROFESSIONAL BURNOUT
}

\begin{abstract}
This study examined the effect of job satisfaction and satisfaction with life on perceptions of teachers' professional burnout and the regulatory role of collective teacher efficacy perception by conducting applied research on teachers who work in different educational settings. The measuring tools were "Maslach Burnout Inventory", "Short Form Minnesota Satisfaction Questionnaire", "Satisfaction with Life Scale" and "Collective Teacher Efficacy Scale". The findings of the research showed that: Teachers' perceptions of job satisfaction and satisfaction with life negatively affected their perceptions of professional burnout. Collective teacher efficacy had a regulatory effect on the relationship between satisfaction with life and professional burnout, and on the relationship between job satisfaction and professional burnout.
\end{abstract}

Key Words: Collective Teacher Efficacy, The Effect of Job Satisfaction, Satisfaction Width Life, Professional Burnout.

\section{Introduction}

Educational organizations like all other organizations should take the behaviour of staff into consideration to achieve the desired goals and increase productivity and quality (Alkış \& Güngörmez, 2015; Selvitopu \& Şahin, 2013). Teachers have always played an essential role in the development and change of societies. Teachers shape the students who are the future of societies. Any kind of behaviour of the teachers in and outside the classroom influences the students and forms a model for them. In other words, teachers determine the future of students who are the future of a society (Recepoğlu, 2013).

One of the most important factors affecting professional life and career of teachers is the perception of professional burnout. The term "burnout" is defined as "exhaustion of physical or emotional strength or motivation usually as a result of prolonged stress or frustration" in Merriam-Webster online dictionary (2018). Herbert Freudenberger first used the concept of burnout in the United States in 1974, who was commonly seen among the professionals

\footnotetext{
1 http://orcid.org/0000-0003-1286-2970/maydogmus@erbakan.edu.tr

2 https://orcid.org/0000-0001-7132-2910/ hserce@selcuk.edu.tr
} 
dealing primarily with human services such as healthcare services, various social services, psychotherapy, legal services and police work in the 1970s (Schaufeli et al., 2009, p. 206).

Empirical studies were carried out by researchers to identify burnout from the early $1980 \mathrm{~s}$ until the mid-1990s because it became a severe problem in various professions, and the interest in it is increasing day by day. Burnout has a negative impact on people's physical and emotional well-being, which leads to low productivity and effectiveness. (Maslach et al., 2001). In Maslach's (1976) definition, burnout comprises three components: "emotional exhaustion", "depersonalization" and "reduced personal accomplishment" (Koçak, 2009, p.67). The feeling of burnout might prevent teachers from coping with alienation or isolation and negative emotions, and enhancing their sense of self-efficacy and competence (Chan, 2011).

Job satisfaction (Leung \& Lee, 2006; Platsidou, 2010; Skaalvik \& Skaalvik, 2009) and satisfaction with life (Avşaroğlu et al., 2005; Özcan, 2016; Soba et al., 2017) are the most critical factors or variables affecting teachers' professional burnout levels. Reduced job satisfaction and emotional satisfaction related to work could lead to professional burnout. A decrease in satisfaction with life as well as an increase in the sense of isolation and emotional deprivation might enhance the perception of professional burnout. In the literature, it is observed that research focuses more on the direct relationship of these two variables with professional burnout. In studies conducted by Skeja (2012) and Toprak (2013), it was found that these variables had significant effects in reducing burnout of employees in different professions. Based on the results of these studies, focusing on these variables in coping with the burnout of employees would affect the professional performance and efficiency positively.

Another important factor affecting the professional life of teachers is job satisfaction. The concept of "satisfaction", which derives from the Latin word "satis" meaning "enough" or "sufficient", can be defined as "fulfilment of something which is desired, being content" (Özaydın \& Özdemir, 2014). Job satisfaction is a topic that has received much attention during the last 75 years. Maslow's (1954) hierarchy of needs theory is the basis of many researchers' discussions and evaluations of job satisfaction. Job has an essential place in the life of an individual. Many employees spend more time in the work environment than at home with his family. Therefore, factors such as the willingness and success of a person at work, a peaceful work environment and adequate compensation for the work are also effective on the person's private life. One may feel a sense of high-satisfaction as well as excessive dissatisfaction at his/ her work. Job satisfaction is influenced by individual factors such as expectation level of the job, social personality trait, work experience, the term of office, education level, age, and gender of the individual; as well as organizational factors such as occupational rights, wages, job security, job reliability, opportunities for promotion, manager relations, colleagues, working conditions, and the nature of the work (Akman, 2018).

Teacher burnout and job satisfaction are important both for the employees and their educational institution. This is because they can affect the quality and the efficiency of the school, and thus the realization of the aims of the school and educational environment. As a result of the burnout, in which a teacher feels not satisfied with the job and expresses it clearly, the quality of education offered by him/her may decline. Therefore, it is necessary to examine teachers' level of satisfaction and professional burnout they experience, reveal their relationship with each other, raise awareness among teachers about this issue, decrease the burn-out level and increase the job satisfaction (Diri \& Kıral, 2016). 
Considerable research has shown the relationship between the variables "job satisfaction" and "burnout". For example, Ertürk and Keçecioğlu (2012) found out that an increase in the level of job satisfaction resulted in a decrease in the level of emotional exhaustion. Gündüz et al. (2013) studying with voluntary workers from different occupations revealed that general job satisfaction significantly predicts emotional exhaustion, a sub-dimension of burnout. Diri and Kıral (2016) showed that teachers' burnout and job satisfaction were significantly correlated, and job satisfaction was a strong predictor. Watts (2013) discovered that general job satisfaction significantly predicted emotional exhaustion and depersonalization dimensions of burnout negatively, and personal achievement dimension positively. Matin et al. (2012) concluded that burnout and job satisfaction were negatively correlated, as lack of job satisfaction was one of the results of job burnout. Chan et al. (2015) found that there was a significant negative relationship between burnout and job satisfaction. Clark (1985) and Igodan (1984) suggested that job dissatisfaction was a predictor of burnout. Furthermore, a negative correlation between burnout and job satisfaction was observed in previous studies (Anbar \& Eker, 2008; George et al., 2008; Matin et al., 2012; Wei \& Abdullah, 2016). In studies on teachers (Özben \& Argun, 2005; Khare \& Kamalian, 2017), a significant relationship was found between these two variables too. As a result, we can say that increasing job satisfaction is recommended to prevent burnout. On the other hand, while interpreting negative occupational and life symptoms such as burnout, investigating the job satisfaction of individuals alone is not enough. Related to satisfaction with life, there are a lot of off-the-job factors. According to Kanten and Kanten (2015), satisfaction with life has an important place among these. Job satisfaction and satisfaction with life are similar in many respects as they generally rely on emotional factors.

"Satisfaction with life" could be considered as another important factor or variable influencing the professional life and career of teachers. It is a psychological feature resulting from people's view of life and the level their expectations are met. It also has an impact on the organizational life of employees. It is a situation obtained by comparing what a person desires to what he/she has and the appraisal of this situation. In other words, it is the result of the expectations of an individual about life and the fulfilment level of these expectations. It refers to the situation of well-being which is related to happiness, morale and others (Özer \& Karabulut, 2003).

Determining the level of satisfaction with life and burnout of teachers is necessary (Soba et al., 2017) due to problems in education. These problems include student-teacher and teacherfamily conflicts, discipline problems, lack of physical conditions, social criticism, social and political pressures, and being generally under more stress than other occupations (Cemaloğlu \& Şahin, 2007, p. 466). Much research has revealed the relationship between satisfaction with life and burnout. Various studies (Anand \& Arora, 2009; Avşaroğlu et al., 2005; Çakınberk, 2011; Demerouti et al., 2000; Gümüş, 2006; Hayes \& Weathington, 2007; Hombrados-Mendieta \& Cosano-Rivas, 2011; Özkan \& Özdevecioğlu, 2012) found out that burnout scores decreased as satisfaction with life scores increased. Çapri et al. (2013) emphasizes that if satisfaction with life increases, it is thought that severe consequences of burnout problems could be avoided. The results of other studies (Anand \& Arora, 2009; Gorji et al., 2015; Özyürek et al., 2012; Şad, 2017) also support that these two variables are negatively correlated, and thus satisfaction with life decreases when burnout increases.

Robinson (2017) argues that low self-efficacy-oriented teachers, who generally perceive themselves as inadequate, focus more on their personal inadequacies and doubt their 
professional competence. Teachers with low-perceived self-efficacy have a tendency to show work displeasure, less effort, lower goals and teaching performance. This is often accompanied by high stress, burnout and depression. Individual self-efficacy and collective self-efficacy consciousness that they displayed with their colleagues in a school culture are important in overcoming this adverse situation.

As one of the most important concepts of Bandura's "Social Cognitive Theory", "collective self-efficacy" is an extension of "self-efficacy" for teams and communities (Bandura, 1997; as cited in, Arıkan \& Çalışkan, 2013). Collective efficacy is defined by Bandura (1997, p. 477) as "a group's shared belief in its conjoint capabilities to organize and execute the courses of action required to produce given levels of attainment". Zaccaro et al. (1995) define the concept of collective competence as "shared competence among individuals when allocating, coordinating, and integrating their resources in a successful concerted response to specific situational demands" (p. 309). Collective efficacy is the sum of individual efficacy beliefs as well as interactive dynamics of the group members. (Goddard et al., 2000).

Research on collective efficacy beliefs reveals that teachers do have not only individualoriented efficacy perceptions but also have efficacy perceptions of teachers' combined capacity in a school. These group-based perceptions reflect a new organizational feature which is defined as collective efficacy (Goddard et al., 2000). Research shows that collective efficacy is one of the important features that improve the quality of teaching, and that a perceived collective efficacy has a strong relationship with student achievement in schools (Burcham, 2009; Jackson, 2009; Knobloch, 2007; Schumacher, 2009; Zafer Güneş, 2014).

A good deal of research has revealed the relationship between collective efficacy and burnout. According to a study by Gürçay et al. (2009), collective self-efficacy and emotional exhaustion were negatively correlated. They also found out that teacher self-efficacy and emotional exhaustion subscale "contribute significantly to predict the collective efficacy beliefs and the whole model explains $34 \%$ of the variance". In another study conducted in order to determine the relationships between burnout, individual and collective efficacy of English language teachers working at university by Kımav (2010), collective efficacy of teachers positively correlated with individual success and negatively correlated with the depersonalization and emotional exhaustion. Furthermore, Smith and Ingersoll (2004) showed that teachers with high collective efficacy were more likely to be satisfied with their jobs. Moreover, Klassen et al. (2010) examined the relationship between the perceptions of teachers' collective efficacy and job satisfaction in Canada, the United States and Korea. In all three cultures, there was a positive correlation between the perception of teachers' collective efficacy and job satisfaction. Other studies (Ahadi et al., 2009; Mortazavi, 2004) revealed a positive and significant relationship between collective efficacy and satisfaction with life, and that collective efficacy was a predictor of satisfaction with life. Because collective efficacy is used as an intermediary variable, it could be assumed that the collective efficacy scale might be a good predictor of satisfaction with life depending on their use and the relationships between variables in research (Safdari \& Galavandi, 2014).

In studies, it was found that there was a negative relationship between collective teacher efficacy and the perception of stress from student behaviours (Klassen, 2010); a positive relationship between job satisfaction and collective teacher efficacy (Klassen et al., 2010); a mediator role of collective teacher efficacy between professional burnout and self-efficacy belief (Skaalvik \& Skaalvik, 2007); a high positive relationship between collective teacher 
efficacy and the trust in colleagues (Lee et al., 2011); and that collective teacher efficacy predicted teachers' organizational loyalty (Ware \& Kitsantas, 2007). These studies clearly show that collective teacher efficacy has a significant impact on the affective characteristics of teachers. It was suggested that teachers with high efficacy beliefs made teaching more qualified, and they were more willing to fulfil their professional responsibilities (TschannenMoran \& Barr, 2004). In this respect, it is thought that collective teacher efficacy beliefs play an important role in the relationship between teachers' job satisfaction and satisfaction with life and professional burnout. Moreover, it could be clearly seen that teachers' job satisfaction, satisfaction with life and collective teacher efficacy beliefs are related to professional burnout. These studies mostly investigated the direct relationship of job satisfaction, satisfaction with life, and the relationship between collective teacher efficacy beliefs and occupational burnout. This study examined the factors that might affect the relationship of professional burnout with job satisfaction and satisfaction with life. Specifically, this study aimed to determine how and at what level the collective teacher efficacy beliefs affect the relationships between these variables. Thus, the hypotheses to be tested according to the following research model were developed.

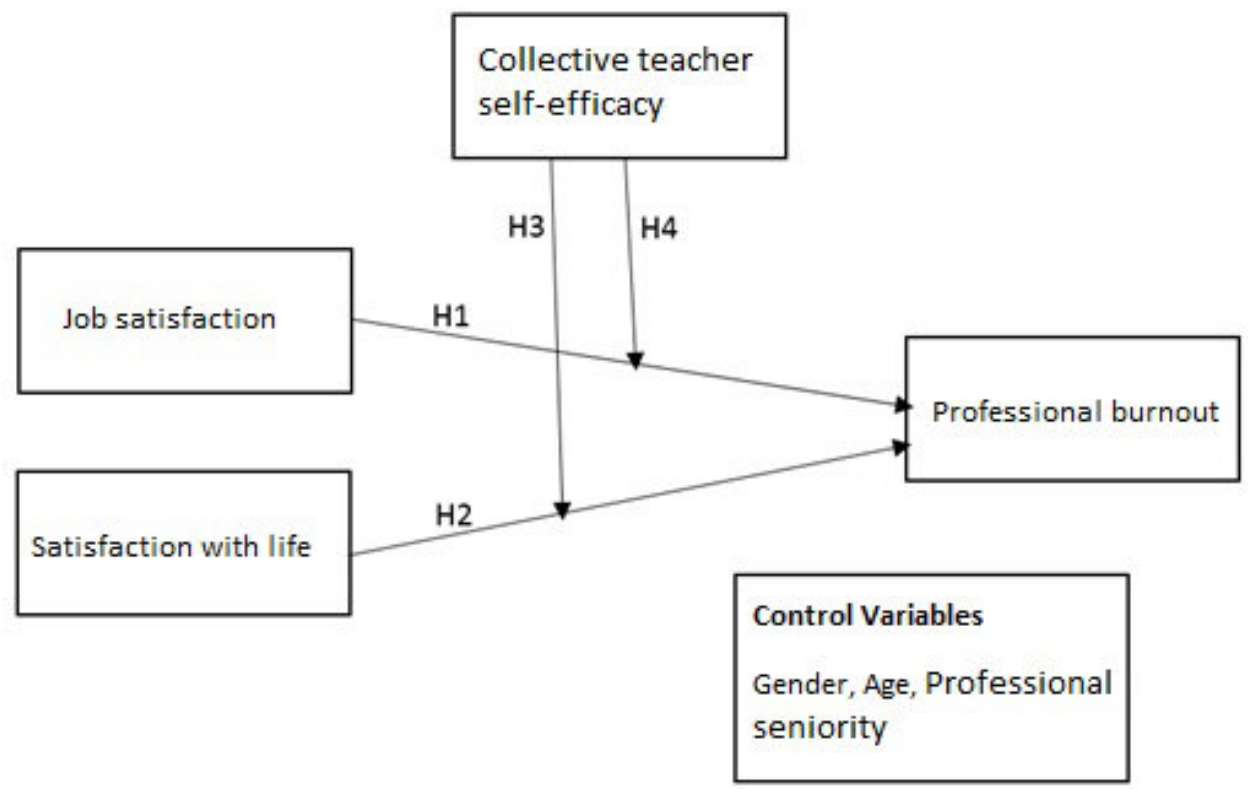

Figure 1. Research Model

H1: Teachers' perceptions of job satisfaction affect the perceptions of professional burnout negatively.

H2: Teachers' perceptions of satisfaction with life affect their perception of occupational burnout negatively.

H3: Collective teacher efficacy beliefs have a regulatory impact on the relationship between teachers' satisfaction with life perceptions and the perceptions of professional burnout.

$\mathrm{H} 4$ : Collective teacher efficacy beliefs have a regulatory impact on the relationship between teachers' job satisfaction perceptions and the perceptions of professional burnout. 


\section{Method}

\section{Research Group}

The research group were 411 teachers working at preschool (5.8\%), primary school (30.9\%), secondary school (36.7\%) and high school (26.5\%). The participants were randomly selected from various schools in the city centre of Konya. $49.9 \%$ of teachers were female, and $50.1 \%$ were male. $16.3 \%$ of them were single, and $83.7 \%$ of them were married. $76.2 \%$ of the teachers had undergraduate education, and $23.8 \%$ of them had graduate education. The average age was 39.28 ( $\mathrm{Sd}=8.20)$, and the average seniority (year) was calculated as $15.34(\mathrm{Sd}=8.17)$. Participation in this study was voluntary.

\section{Research Instruments}

Maslach Burnout Inventory: Developed by Maslach and Jackson (1985) and adapted to Turkish by Ergin (1992), the inventory evaluates burnout levels. It comprises twenty-two items in three sub-dimensions: emotional exhaustion (nine items), depersonalization (five items) and personal achievement (eight items). The five-point Likert-type inventory includes answers as "never (1)", "very rare (2)", "sometimes (3)", "often (4)" and "always (5)". A high score from the inventory is interpreted as a high level of perceived burnout. Cronbach's alpha internal consistency coefficients computed in this study were $0.82,0.75$ and 0.73 for the abovementioned sub-dimensions respectively.

Short Form Minnesota Satisfaction Questionnaire (SFMSQ): Originally developed by Weiss et al. (1967), SFMSQ evaluates internal and external dimensions of job satisfaction with its twenty items. The five-point Likert-type scale is formed as "very dissatisfied (1)", "dissatisfied (2)", "neither satisfied nor dissatisfied (3)", "satisfied (4)", and "very satisfied (5)". The final score from the scale is calculated by dividing the sum total obtained from the items by 20 . The higher the score is the higher the perception of job satisfaction. Cronbach's alpha internal consistency coefficients calculated in this study were 0.85 and 0.88 for the internal and external dimensions respectively.

Satisfaction with Life Scale: Developed by Diener et al. (1985) and adapted to Turkish by Dağlı and Baysal (2016), the scale has a single factor with five items. The five-point Likert-type scale is scored as "I strongly disagree (1)", "I slightly disagree (2)", "I slightly agree (3)", "I agree (4)", and "I strongly agree (5)". A high score from the scale indicates a high level of perceived satisfaction with life. Cronbach Alpha internal consistency coefficient of the scale was calculated as 0.89 .

Collective Teacher Efficacy Scale: Developed by Tschannen-Moran and Barr (2004) and adapted to Turkish by Erdoğan and Dönmez (2015), the scale comprises twelve items to assess collective teacher efficacy with two sub-dimensions. Each dimension - student discipline and teaching strategies - has six items. The five-point Likert-type scale is graded as "no (1)", "less (2)", "medium (3)", "too (4)" and "completely (5)". The higher the score from the scale is the higher the perceived collective teacher efficacy. Cronbach Alpha internal consistency coefficients we calculated for the above-mentioned dimensions were found as 0.83 and 0.85 respectively.

\section{The Statistical Analysis of Data}

Hierarchical regression analysis was performed to test the hypotheses developed for the study. In the first stage of the regression analysis, control variables and independent variables were included. The moderator variable was added in the second stage. In the third and last stage, interaction variables were added to the model. Finney and DiStefano (2006) states that a univariate kurtosis of less than 7 and skewness of less than 2 is acceptable for normality. The 
kurtosis and skewness values of the variables in the study ranged from -0.26 to 0.85 and -0.25 to 0.33 respectively. Therefore, it can be said that the data were normally distributed. Moreover, no multicollinearity problem was found between the variables $(\mathrm{VIF}<10, \mathrm{TV}>0.10)$. In order to express the regulatory effects better, graphs were formed and analyzed based on the regression curves. Data were analyzed through SPSS 25.0.

\section{Findings}

For the purpose of the study, the averages, standard deviations and relations between these data were calculated. The results are given in Table 1.

Table 1. Relationships between Perceived Professional Burnout, Job Satisfaction, Satisfaction with Life and Collective Teacher Efficacy

\begin{tabular}{|c|c|c|c|c|c|c|}
\hline Variables & $\mathbf{M}$ & Sd & 1. & 2. & 3. & 4. \\
\hline 1. Job burnout & 2,115 & 0,489 & 1 & & & \\
\hline 2. Job satisfaction & 3,619 & 0,665 &,$- 627^{* *}$ & 1 & & \\
\hline 3. Satisfaction with life & 3,064 & 0,869 &,$- 458^{* *}$ &, $640^{* *}$ & 1 & \\
\hline 4. Collective teacher efficacy & 3,397 & 0,590 &,$- 289^{* *}$ &, $375^{* *}$ &, $228^{* *}$ & 1 \\
\hline
\end{tabular}

Table 1 shows that, professional burnout negatively and significantly correlated with job satisfaction $(r=-0.627 ; p<0.01)$, satisfaction with life $(r=-0.458 ; p<0.01)$ and collective teacher efficacy $(r=-0.289 ; p<0.01)$. Additionally, job satisfaction positively and significantly correlated with satisfaction with life $(r=0.640 ; p<0.01)$ and collective teacher efficacy $(r=0.375 ; p<0.01)$. Finally, there was a positive and statistically significant relationship between satisfaction with life and collective teacher efficacy $(r=0.228 ; p<0.01)$. Significant relationships were found between dependent and independent variables in the study. Therefore, significant effects can be predicted among the variables.

Table 2. Hierarchical Regression Analysis for the Effects of Job Satisfaction and Collective Teacher Efficacy on Professional Burnout

\begin{tabular}{|c|c|c|c|}
\hline Predictors & $\begin{array}{c}\text { Model } 1 \\
\beta\end{array}$ & $\frac{\text { Model } 2}{\beta}$ & $\frac{\text { Model } 3}{\beta}$ \\
\hline Gender $^{a}$ & $0,082^{*}$ & $0,081 *$ & 0,064 \\
\hline Age & $-0,099$ & $-0,113$ & $-0,094$ \\
\hline Professional seniority & 0,022 & 0,033 & 0,020 \\
\hline Job satisfaction (JS) & $-0,626 * * *$ & $-0,600 * * *$ & $-0,578 * * *$ \\
\hline Collective teacher efficacy (CTE) & & $-0,066$ & $-0,058$ \\
\hline JS X CTE & & & $0,117 * * *$ \\
\hline$\Delta \mathrm{R}^{2}$ & 0,400 & 0,004 & 0,013 \\
\hline$\Delta \mathrm{F}$ & $67,571 * * *$ & 2,543 & $8,734 * * *$ \\
\hline $\mathrm{R}^{2}$ & 0,400 & 0,404 & 0,417 \\
\hline Adjusted $\mathrm{R}^{2}$ & 0,394 & 0,397 & 0,408 \\
\hline $\mathrm{F}$ & $67,572 * * *$ & $54,772 * * *$ & $47,973 * * *$ \\
\hline
\end{tabular}

${ }^{*} p<0,05 ;{ }^{* * *} p<0,001 ;{ }^{a} 0=$ female; 1 = male.

So as to test the hypotheses, the first hierarchical regression analysis (Table 2) included control variables of participants (gender, age, professional seniority) and job satisfaction as independent variables, professional burnout as the dependent variable, and collective teacher efficacy as the moderator variable. The results revealed that the relationship between job 
satisfaction and professional burnout was negative and statistically significant ( $\beta=-0.626$; $\mathrm{p}<0.001$ ), and gender, age, seniority and job satisfaction explained $40 \%$ of the variance in professional burnout. Thus, $\mathrm{H}_{1}$ hypothesis was confirmed. Teachers' perceptions of job satisfaction affected the perception of professional burnout negatively.

In the next step of the regression model, collective teacher efficacy was added as an independent variable. The analysis showed a negative and statistically insignificant relationship between collective teacher efficacy and professional burnout ( $\beta=-0.066 ; p>0.05$ ). Then, the interaction between job satisfaction and collective teacher efficacy was added to the model. The analysis demonstrated that the interaction between job satisfaction and collective teacher efficacy had a positive relationship with professional burnout $(\beta=0.117$; $\mathrm{p}<0.001)$. Thus, $\mathrm{H}_{4}$ hypothesis was accepted. Collective teacher efficacy had a regulatory impact on the relationship between job satisfaction and professional burnout.

To express the regulatory effect better, a graph was generated and analysed based on the regression curves (Figure 2). According to the graph presented in Figure 2, collective teacher efficacy weakens the relationship between job satisfaction and professional burnout. As collective teacher efficacy beliefs increase, the strength of the relationship between job satisfaction and professional burnout decreases.

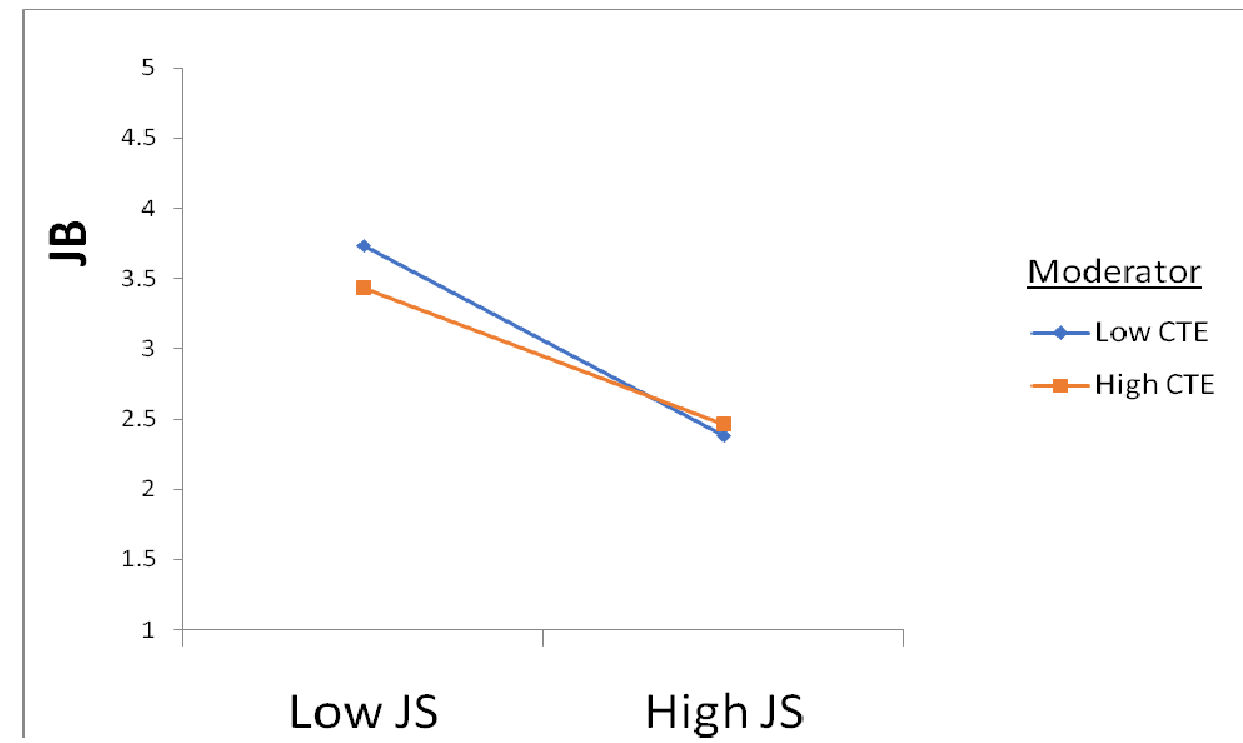

Figure 2. Regulatory Effect of Collective Teacher Efficacy on the Relationship between Job Satisfaction and Professional Burnout (JB=Job burnout, JS= Job satisfaction, CTE= Collective teacher efficacy) 
Table 3. Hierarchical Regression Analysis Results of the Effects of Satisfaction with Life and Collective Teacher Efficacy on Professional Burnout

\begin{tabular}{|c|c|c|c|}
\hline Predictors & Model 1 & Model 2 & Model 3 \\
\hline Gender ${ }^{\mathrm{a}}$ &, 038 & ,040 & ,027 \\
\hline Age &,$- 272^{*}$ &,$- 291 * *$ &,$- 263^{*}$ \\
\hline Professional seniority & 180 & 192 & 161 \\
\hline Satisfaction with life (SL) &,$- 451 * * *$ &,$- 406 * * *$ &,$- 396 * * *$ \\
\hline Collective teacher efficacy (CTE) & &,$- 201 * * *$ &,$- 197 * * *$ \\
\hline SL X CTE & & &, $175 * * *$ \\
\hline$\Delta \mathrm{R}^{2}$ & 0,223 & 0,038 & 0,030 \\
\hline$\Delta \mathrm{F}$ & $29,067 * * *$ & $20,881 * * *$ & $17,242 * * *$ \\
\hline $\mathrm{R}^{2}$ & 0,223 & 0,261 & 0,292 \\
\hline Adjusted $\mathrm{R}^{2}$ & 0,215 & 0,252 & 0,281 \\
\hline $\mathrm{F}$ & $29,067 * * *$ & $28,571 * * *$ & $27,640 * * *$ \\
\hline
\end{tabular}

${ }^{*} p<0,05 ;{ }^{* *} p<0,01 ; * * * p<0,001 ;{ }^{a} 0=$ female; 1 = male.

To test the other hypotheses of the study, the second hierarchical regression analysis included control variables of participants (gender, age, professional experience) and satisfaction with life as independent variables, professional burnout as the dependent variable, and collective teacher efficacy as the moderator variable (Table 3). The results showed that the relationship between satisfaction with life and professional burnout was negative and statistically significant $(\beta=-0.451 ; p<0.001) ;$ gender, age, professional seniority and job satisfaction explained $22 \%$ of the variance in professional burnout. Accordingly, $\mathrm{H}_{2}$ hypothesis was supported. Teachers' perceptions of satisfaction with life affected their perceptions of professional burnout negatively.

In the next step of the regression model, collective teacher efficacy was added as an independent variable. The results revealed a negative and statistically significant relationship between collective teacher efficacy and professional burnout $(\beta=-0.201 ; p<0.001)$. Then, the interaction between satisfaction with life and collective teacher competence was included in the model. According to the results, the interaction between satisfaction with life and collective teacher competence had a positive relationship with professional burnout $(\beta=0.175$; $\mathrm{p}<0.001)$. Therefore, $\mathrm{H}_{3}$ hypothesis was supported. The relationship between satisfaction with life and professional burnout had a regulatory impact on collective teacher efficacy.

So as to express the regulatory effect better, a graph was generated and analysed based on the regression curves (Figure 3). The graph presented below shows that collective teacher efficacy weakens the relationship between satisfaction with life and professional burnout. As the perceptions of collective teacher efficacy increase, the strength of the relationship between satisfaction with life and professional burnout decreases. 


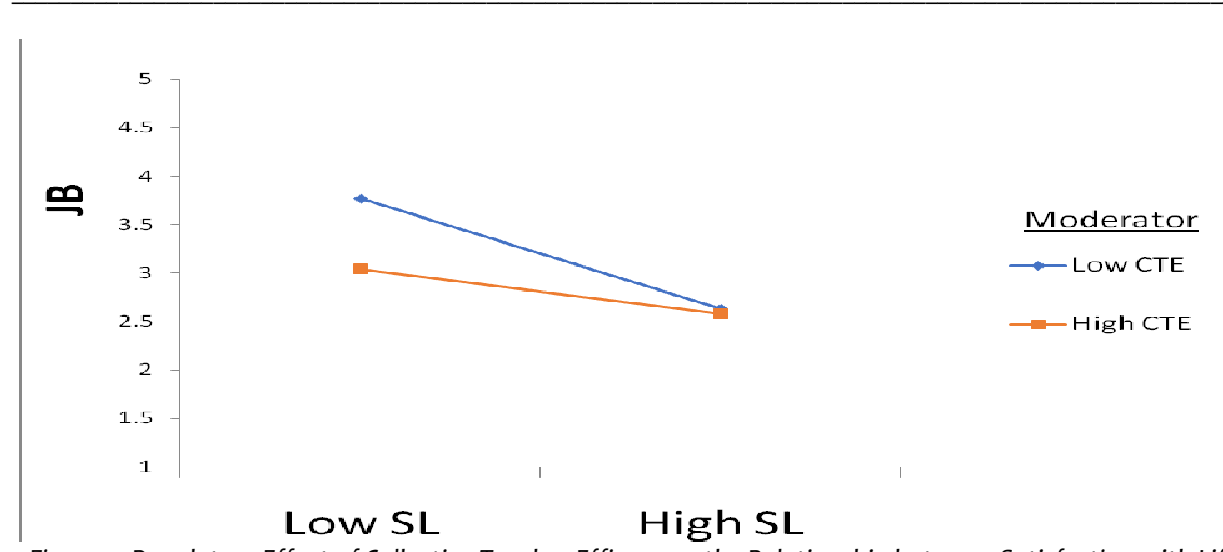

Figure 3. Regulatory Effect of Collective Teacher Efficacy on the Relationship between Satisfaction with Life and Professional Burnout (JB= Job burnout, $S L=$ Satisfaction with life, CTE=Collective teacher efficacy)

\section{Discussion}

This study investigated the effect of job satisfaction and satisfaction with life on teachers' perceptions of professional burnout, and the regulatory role of collective teacher efficacy beliefs on this effect. The effects of the variables included in the analysis on the perception of professional burnout were presented by hierarchical regression analysis. The results of the research revealed descriptive findings with respect to the relations in the teaching profession between job satisfaction and professional burnout, and satisfaction with life and professional burnout.

The results of the analysis show that teachers' perceptions of job satisfaction and satisfaction with life are related to their perceptions of professional burnout, and these variables decrease the occupational burnout significantly and negatively. The findings corroborate previous literature research. There are studies indicating a negative and significant relationship between job satisfaction and professional burnout (Anbar \& Eker, 2008; Diri \& Kıral, 2016; Ertürk \& Keçecioğlu, 2012; George et al., 2008; Gündüz et al., 2013; Kavlu \& Pınar, 2009; Khare \& Kamalian, 2017; Özben \& Argun, 2005; Watts, 2013; Wei \& Abdullah, 2016). Similarly, studies indicate a negative and statistically significant relationship between satisfaction with life and professional burnout. (Anand \& Arora, 2009; Çakınberk, 2011; Demerouti et al., 2000; Gorji et al., 2015; Hayes \& Weathington, 2007; Hombrados-Mendieta \& Cosano-Rivas, 2011; Özkan \& Özdevecioğlu, 2012; Özyürek et al., 2012; Şad, 2017).

Job satisfaction can be defined as the difference between the amount individuals receive and the amount they believe they should receive. Burnout, on the other hand, is the depletion of energy, both mentally and physically. Burnout is a condition that has significant effects on individuals and organizations. Therefore, an individual with burnout exhibits low performance and inappropriate behaviours, and has difficulty focusing on his work (Naktiyok \& Kaygın, 2012). It has been observed that expectations of individuals related to occupations and institutions trigger or reduce burnout. Job satisfaction is affected by institutional and environmental factors like the content of the work, compensation, working conditions, working time, workload, disruption in organizational functioning, inequality in the workplace, lack of staff as well as individual factors such as age, gender and education level (Güllüce \& Işcan, 2010, p. 9). 
Studies reveal negative relationships between job satisfaction and burnout. As job satisfaction increases, burnout decreases. Thus, it could be argued that if the difference between the expectations of a person and the results that he/she receives is in favour of the results, it will lead to an increase in his/her mental and physical energy. However, if the difference is in favour of the expectations, the difference will cause a decrease in mental and physical energy.

Satisfaction with life is a condition obtained by comparing what a person desires to what he/she has and the appraisal of this situation. In other words, satisfaction with life is the result of the expectations of an individual about life and the fulfilment level of these expectations. It refers to the situation of well-being, which relates to happiness, morale and others (Özer \& Karabulut, 2003; Vara, 1999, as cited in Recepoğlu, 2013). In short, satisfaction with life can be defined as the difference between the expectations of life outside work and the results he/she receives, similar to the definition given for job satisfaction. When the factors causing individuals to experience burnout are examined, it could be argued that factors affecting satisfaction with life cause burnout as well. An individual who is dissatisfied with the effect of similar factors can experience burnout (Oruç, 2007, p. 17).

It is thought that job satisfaction and satisfaction with life affect teachers' perceptions of professional burnout, and this effect could be reflected in output variables through some variables. From this point of view, the regulatory role of collective teacher efficacy in the effect of job satisfaction and satisfaction with life on professional burnout was investigated. The findings show that there is the role of collective teacher efficacy in the effect of both job satisfaction and satisfaction with life on professional burnout. As collective teacher efficacy beliefs increase, the strength of the relationships between job satisfaction and professional burnout, and satisfaction with life and professional burnout weakens.

According to the literature review by Ünal (2015), it was found that individuals with higher perceptions of satisfaction with life were more successful in their social and romantic relationships, more responsive to events and situations, and more adaptable to social life. In addition, they were more energetic and creative, healthier, more successful in marriage, had longer life span, higher work performance and productivity, and were more successful in adapting to organization.

The low perception of job satisfaction affects teacher motivation. Especially unhappy and dissatisfied teachers affect the motivation and performance of their colleagues negatively (Lashway, 1997). Job dissatisfaction generally leads to an unwillingness to go to work, tendency to quit work, not to cooperate, to develop a sense of inadequacy, not to make accurate decisions, and to a decrease in the quantity and quality of the work (Vecchio, 1988). Research findings show that low job satisfaction or job dissatisfaction leads to a high perception of burnout. Individuals experiencing burnout feel tired and emotionally exhausted. Their emotional resources are depleted, and they feel a lack of energy (Maslach \& Goldberg, 1998). Depersonalization and callousness are observed in individuals experiencing burnout (Togia et al., 2004). A sense of failure is experienced in relationships with the people encountered in the workplace, and a feeling of inadequacy emerges in various work-related events due to the fact that sense of reduced personal accomplishment becomes negative selfappraisal of the person (Özkaya, 2006). It could be argued that the characteristics of individuals experiencing burnout overlap with job dissatisfaction and dissatisfaction with life. Collective efficacy is defined as the belief in the joint capabilities of teachers in the school. If this belief is high, the perception of job satisfaction and satisfaction with life is high, and the perception of burnout is expected to be low. 
Considering the role of collective teacher efficacy in reducing the strength of the relationship between job satisfaction, occupational burnout and job satisfaction, it could be claimed that conducting studies to support the collective teacher efficacy will increase the perception levels of teachers about job satisfaction and satisfaction with life, and accordingly decrease perception levels related to burnout. In this context, it is necessary to improve collective teacher efficacy. According to Çalık et al. (2012), instructional leadership is an effective premise in the construction of collective efficacy, and the findings indicate that the instructional leadership with its all sub-dimension have significant relationships with collective teacher efficacy. Thus, it could also be assumed that instructional leaders can increase teachers' collective and self-efficacy. Jhanke (2010) listed some of the factors that influence the improvement of collective efficacy as "a positive and supportive environment", "clear and apparent vision and objectives", "high expectations", "meaningful professional development" and "shared leadership".

It was determined that perceptions of job satisfaction and satisfaction with life were related to perceptions of professional burnout, and these variables reduced professional burnout significantly and negatively. As the level of satisfaction from work - chosen consciously and intentionally, and done with love - increases, burnout can decrease. Efforts towards increasing teachers' job satisfaction (personal rights, organizational culture, and so on.) could be made. Decisions could be taken to encourage teamwork in institutions. The number of social activities carried out in institutions for teachers could be increased. Starting a teaching profession should be seen as the beginning, not the end, of career planning. Thus, legal arrangements could be made to encourage teachers' performance and personal development. Joining decision-making gives teachers a sense of ownership, promise and authority.

This study has some limitations. Firstly, the research was conducted only with teachers, an important limitation. Further studies can elaborate on the findings of this study more if different target groups are included. In addition, this is a quantitative study and qualitative studies that will explore the relationships between variables more closely can contribute to having a holistic and integrated view. Regulatory roles of different variables in the relationship between job satisfaction and satisfaction with life could be investigated. Moreover, the findings of this study are limited only to the self-reports of the participants. The sources of teachers' job satisfaction, satisfaction with life, professional burnout and self-efficacy, and related variables can be explored in a multifaceted way with the views of other stakeholders in education.

\section{References}

Ahadi, B., Narimani, M., Abolghasemi, A., \& Asiaei, M. (2009). Investigating the relationship between emotional intelligence, attribution style, self-efficacy and life satisfaction in employed women. Journal of Education and Psychology Studies of Ferdowsi University of Mashhad, 10(1), 118-127.

Akman, Z. (2018). Belediye çalışanlarının iş tatmini üzerine bir araştırma: Erzincan belediyesi örneği (Unpublished master's thesis). Erzincan Binali Yıldırım Üniversitesi, Sosyal Bilimler Enstitüsü, Erzincan. 
Alkış, H., \& Güngörmez, E. (2015). Örgütsel adalet algısı ile performans arasındaki ilişki: Adıyaman ili örneği. Adıyaman Üniversitesi Sosyal Bilimler Enstitüsü Dergisi, 21, 937 967.

Anand, M., \& Arora, D. (2009). Burnout, life satisfaction and quality of life among executives of multi-national companies. Journal of the Indian Academy of Applied Psychology, 35(1), 159-164.

Anbar, A., \& Eker, M. (2008). An examination of relationship between burnout and job satisfaction among Turkish Accounting and Finance academicians. European Journal of Economic and Political Studies (EJEPS), 1(1): 46-67.

Arıkan, S., \& Çalışkan, S. C. (2013). “Kolektif yeterlik” üzerine yeni bağımsız değişken arayışları: Lider-üye etkileşimi’nin kolektif yeterlik üzerindeki etkisi üzerine bir araştırma. Türk Psikoloji Dergisi, 28(71), 1-16.

Avşaroğlu, S., Deniz, M. E., \& Kahraman, A. (2005). Teknik öğretmenlerde yaşam doyumu iş doyumu ve mesleki tükenmişlik düzeylerinin incelenmesi. Selçuk Üniversitesi Sosyal Bilimler Enstitüsü Dergisi, (14), 115-129.

Burcham, M. W. (2009). The impact of collective teacher efficacy on student achievement in high school science (Unpublished doctoral dissertation). Gardner-Web University.

Çakınberk, A. (2011). Studying the relationship between employees' occupational burnout levels and satisfaction of life: A research in private banks. African Journal of Business Management, 5(16), 6825-6838.

Çalık, T., Sezgin, F., Kavgacı, H., \& Kılınç, A. Ç. (2012). Okul müdürlerinin öğretim liderliği davranışları ile öğretmen öz yeterliği ve kolektif öğretmen yeterliği arasındaki ilişkilerin incelenmesi. Kuram ve Uygulamada Eğitim Bilimleri, 12(4), 2487-2504.

Çapri, B., Gündüz, B., \& Akbay, S. E. (2013). The study of relations between life satisfaction, burnout, work engagement and hopelessness of high school students. International Education Studies, 6(11), 35-46.

Cemaloğlu, N., \& Şahin, E. D. (2007). Öğretmenlerin mesleki tükenmişlik düzeylerinin farklı değişkenlere göre incelenmesi. Kastamonu Eğitim Dergisi, 15(2), 465-484.

Chan, C. M., Chong, S. M., Chong, Y. S., \& Tang, C. U. (2015). The influence of job stress, burnout and job satisfaction among primary school teachers in Ipoh. Final Year Project, Universiti Tunku Abdul Rahman.

Chan, D. W. (2011). Burnout and life satisfaction: Does gratitude intervention make a difference among Chinese school teachers in Hong Kong?. Educational Psychology, 31(7), 809-823.

Clark, R. W. (1985). Burnout and associated factors among administrators/mid-managers of the cooperative extension service in the North central region (Unpublished doctoral dissertation). The Ohio State University, Columbus, $\mathrm{OH}$.

Dağlı, A., \& Baysal, N. (2016). Yaşam doyumu ölçeğinin Türkçe'ye uyarlanması: Geçerlik ve güvenirlik çalışması. Elektronik Sosyal Bilimler Dergisi, 15(59), 1250-1262.

Demerouti, E., Bakker A. B., Nachreiner, F., \& Schaufeli, W. B. (2000). Model of burnout and life satisfaction amongst nurses. Journal of Advanced Nursing, 32(2), $454-464$.

Diener, E., Emmons, R. A., Larsen, R. J., \& Griffin, S. (1985). The satisfaction with life scale. Journal of Personality Assessment, 49(1), 71-75.

Diri, M. S., \& Kıral, E. (2016). Ortaokul öğretmenlerinin iş doyumlarının mesleki tükenmişlik düzeylerine etkisi. Mehmet Akif Ersoy Üniversitesi Eğitim Fakültesi Dergisi, 1(39), 125149.

Erdoğan, U., \& Dönmez, B. (2015). Kolektif öğretmen yeterliği ölçeğinin Türkçeye uyarlanması: Geçerlik ve güvenirlik çalışması. Kuram ve Uygulamada Eğitim Yönetimi Dergisi, 21(3), 345-366. 
Ergin, C. (1992). Doktor ve hemşirelerde tükenmişlik ve Maslach Tükenmişlik Ölçeği'nin Uyarlanması. Paper presented at 7th Ulusal Psikoloji Kongresi. Ankara: Psikologlar Derneği Yayınları.

Ertürk, E., \& Keçecioğlu, T. (2012). Çalışanların iş doyumları ile mesleki tükenmişlik düzeyleri arasındaki ilişkiler: Öğretmenler üzerine örnek bir uygulama. Ege Akademik Bakış, 12(1), 39-52.

Finney, S. J., \& DiStefano, C. (2006). Non-normal and categorical data in structural equation modeling. In G. R. Hancock, \& R. D. Mueller (Eds.), Structural equation modeling: A second course (pp. 269-314). Charlotte: Information Age.

George, E., Louw, D., \& Badenhorst, G. (2008). Job satisfaction among urban secondary-school teachers in Namibia. South African Journal of Education, 28, 135-154

Goddard, R. D., Hoy, W. K., \& Hoy, W. A. (2000). Collective teacher efficacy: It's meaning, measure, and impact on student achievement. American Education Research Journal, $37(2), 479-507$.

Gorji, A. M., Teimuri, F., Gorji, M. A., \& Gorji, R. (2015). Job burnout and life satisfaction among nurses and midwives of medical institutions in Northern Iran: A cross-sectional study. Tropical Journal of Medical Research, 18(1), 34.

Güllüce, A. Ç., \& İşcan, Ö. F. (2010). Mesleki tükenmişlik ve duygusal zeka arasındaki ilişsi. Eskişehir Osmangazi Üniversitesi IïF Dergisi, 5(2), 7-29.

Gümüş, H. (2006). Farklı mesleklerde çalışanların iş ve yaşam doyumlarının tükenmişlik düzeyleri açısından karşılaştırılması (Unpublished doctoral dissertation). Atatürk Üniversitesi, Erzurum.

Gündüz, B., Çapri, B., \& Gökçakan, Z. (2013). Mesleki tükenmişlik, işle bütünleşme ve iş doyumu arasındaki ilişkilerin incelenmesi . Eğitim Bilimleri Araştırmaları Dergisi , 3(1), $29-49$.

Gürçay, D., Yılmaz, M., \& Ekici, G. (2009). Öğretmen kolektif yeterlik inancını yordayan faktörler. Hacettepe Üniversitesi Eğitim Fakültesi Dergisi, 36(36), 119-128.

Hayes, C. T., \& Weathington, B. L. (2007). Optimism, stress, life satisfaction, and job burnout in restaurant managers. The Journal of Psychology, 141(6), 565-579.

Hombrados-Mendieta, I., \& Cosano-Rivas, F. (2011). Burnout, workplace support, job satisfaction and life satisfaction among social workers in Spain: A structural equation model. International Social Work, 56(2), 228-246.

Igodan, O. C. (1984). Factors associated with burnout among extension agents in the Ohio cooperative extension service (Unpublished doctoral dissertation). The Ohio State University.

Jackson, J. C. (2009). Organizational citizenship behaviors, collective teacher efficacy, and student achievement in elementary schools (Unpublished doctoral dissertation). The College of William and Mary in Virginia.

Jhanke, M. S. (2010). How teacher collective efficacy is developed and sustained in high achieving middle schools (Unpublished doctoral dissertation). College of Education and Leadership Cardinal Stritch University, United States.

Kanten, P., \& Kanten, S. (2015). İş yaşamının kalitesinin yaşam doyumu üzerindeki etkisinde iş doyumunun aracılık rolü. In S. Doğan (Ed.), Yaşam doyumu seçme konular (pp. 39-72). Ankara: Nobel Akademik Yayıncılık.

Kavlu, i., \& Pınar, R. (2009). Acil servislerde çalışan hemşirelerin tükenmişlik ve iş doyumlarının yaşam kalitesine etkisi. Türkiye Klinikleri J Med Sci, 29(6), 1543-1555.

Khare, A., \& Kamalian, A. (2017). Studying relationship between job satisfaction and burnout (Case study: HSE managers in Karajroad Industries). The Journal of Internet Banking and Commerce, 22(1), 1-13. 
Kımav, A. U. (2010). An exploration of burnout and individual and collective teacher efficacy in a Turkish state university (Unpublished master's thesis). Bilkent University, Ankara, Turkey.

Klassen, R. M. (2010). Teacher stress: The mediating role of collective efficacy beliefs. The Journal of Educational Research, 103(5), 342-350.

Klassen, R. M., Usher, E. L., \& Bong, M. (2010). Teachers' collective efficacy, job satisfaction, and job stress in cross-cultural context. The Journal of Experimental Education, 78(4), 464-486.

Knobloch, S. F. (2007). Teacher participation in decision making and collective efficacy (Unpublished doctoral dissertation). Virginia: University of Virginia.

Koçak, R. (2009). Okul yöneticilerinin mesleki tükenmişlik düzeylerinin bazı değişkenler açısından incelenmesi. Fırat Üniversitesi Sosyal Bilimler Dergisi, 19(1), 65-83.

Lashway, L. (1997). Multidimensional school leadership. Bloomington, IN: Phi Delta Kappa Foundation.

Lee, J. C. K., Zhang, Z., \& Yin, H. (2011). A multilevel analysis of the impact of a professional learning community, faculty trust in colleagues and collective efficacy on teacher commitment to students. Teaching and Teacher Education, 27(5), 820-830.

Leung, D. Y. P., \& Lee, W. W. S. (2006). Predicting intention to quit among Chinese teachers: Differential predictability of the components of burnout. Anxiety, Stress \& Coping, 19(2), 129-141.

Maslach, C., \& Goldberg, J. (1998). Prevention of burnout: New perspectives. Applied and Preventive Psychology, 7(1), 63-74.

Maslach, C., \& Jackson, S. E. (1985). The role of sex and family variables in burnout. Sex Roles, $12,837-851$.

Maslach, C., Schaufeli, W.B., \& Leiter, M. P. (2001). Job burnout. Annual Review of Psychology, 52, 397-422.

Maslow, A. (1954). Motivation and personality. New York: Harper.

Matin, H. Z., Kalali, N. S., \& Anvari, M. R. A. (2012). Do demographic variables moderate the relationship between job burnout and its consequences? Iranian Journal of Management Studies, 5(1), 47-62.

Merriam-Webster Dictionary. Available from www.merriam-webster.com, 9 August 2018.

Mortazavi, S. (2004). Mutual relationships between self-efficacy and perceived support by families, teachers and close friends. Edu. Innovations Quarterly, 3(8), 13-39.

Naktiyok, A., \& Kaygın, E . (2012). Tükenmişlik ve iş tatmini düzeylerini belirlemeye yönelik akademik personel üzerinde bir uygulama. Sosyal ve Beşeri Bilimler Dergisi, 4(1), 23-32.

Oruç, S. (2007). Özel eğitim alanında çalışan öğretmenlerin tükenmişlik düzeylerinin bazı değişkenler açısından incelenmesi (Adana ili örneği) (Unpublished master's thesis). Çukurova Üniversitesi, Adana.

Özaydın, M. M., \& Özdemir, Ö. (2014). Çalışanların bireysel özelliklerinin iş tatmini üzerindeki etkileri: Bir kamu bankası örneği. iş̧letme Araştırmaları Dergisi, 6(1), 251-281.

Özben, Ş., \& Argun, Y. (2005). Sosyo-demografik özelliklere göre ilköğretim öğretmenlerinin iş doyumu ve tükenmişlik düzeylerinin incelenmesi. Dokuz Eylül Üniversitesi Buca Eğitim Fakültesi Dergisi, 18, 27-37.

Özcan, E. (2016). Özel eğitim okulunda görev yapan öğretmenlerin tükenmişlik düzeylerinin karşılaştırılması (Unpublished master's thesis). Ufuk Üniversitesi, Sosyal Bilimler Enstitüsü, Ankara.

Özer, M., \& Karabulut, Ö. Ö. (2003). Yaşlılarda yaşam doyumu. Geriatri, 6(2), 72-74.

Özkan, A., \& Özdevecioğlu, M. (2012). The effects of occupational stress on burnout and life satisfaction: a study in accountants. Quality \& Quantity, 47, 2785-2798. 
Özkaya, H. (2006). Yatılı ilköğretim bölge okulu ve ilköğretim okullarında görev yapan öğretmenlerin tükenmişlik düzeylerinin öğretmen görüşleri açısından karşılaştırılması (Unpublished master's thesis). Onsekiz Mart üniversitesi, Çanakkale.

Özyürek, A., Gümüş, H., \& Doğan, S. (2012). Öğretmen ve okul yöneticilerinin tükenmişlik ve yaşam doyumunun incelenmesi. Uluslararası Insan Bilimleri Dergisi, 9(2), 892-904.

Platsidou, M. (2010). Trait emotional intelligence of Greek special education teachers in relation to burnout and job satisfaction. School Psychology International, 31(1), 60-76.

Recepoğlu, E. (2013). Öğretmen adaylarının yaşam doyumları ile öğretmenlik mesleğine ilişkin tutumları arasındaki ilişkinin incelenmesi. Hacettepe Üniversitesi Eğitim Fakültesi Dergisi (H. U. Journal of Education), Özel Sayı (1), 311-326.

Robinson, S. (2017). Fostering motivation and teacher self-efficacy using the guided reading method (Unpublished doctoral dissertation). Concordia University - Portland.

Şad, B. (2017). Konaklama işletmelerinde çalışan bireylerin tükenmişlik düzeylerinin yaşam doyumuna etkisi (Unpublished master's thesis). Balıkesir Üniversitesi, Sosyal Bilimler Enstitüsü, Balıkesir.

Safdari, K., \& Galavandi, H. (2014). Study of the relationship between life skills and collective teacher efficacy with life satisfaction among high school teachers. Trend Life Sci, 3, 621-635.

Schaufeli, W. B., Leiter, M. P., \& Maslach, C. (2009). Burnout: 35 years of research and practice. Career Development International, 14(3), 204-220.

Schumacher, D. F. (2009). Collective teacher efficacy and student achievement (Unpublished doctoral dissertation). Mzcomb: Western Illinois University.

Selvitopu, A., \& Şahin, H. (2013). Ortaöğretim öğretmenlerinin örgütsel adalet algıları ile örgütsel bağlılıkları arasındaki ilişki. Ahi Evran Üniversitesi, Kırşehir Eğitim Fakültesi Dergisi (KEFAD), 14(2), 171-189.

Skaalvik, E. M., \& Skaalvik, S. (2007). Dimensions of teacher self-efficacy and relations with strain factors, perceived collective teacher efficacy, and teacher burnout. Journal of Educational Psychology, 99(3), 611-625.

Skaalvik, E. M., \& Skaalvik, S. (2009). Does school context matter? Relations with teacher burnout and job satisfaction. Teaching and Teacher Education, 25(3), 518-524.

Skeja, A., (2012). Çalışanların tükenmişlik düzeyi ile iş tatmini arasındaki ilişki ve bir araştırma (Unpublished master's thesis). İstanbul Üniversitesi, Sosyal Bilimler Enstitüsü, İstanbul.

Smith, T. M., \& Ingersoll, R. M. (2004). What are the effects of induction and mentoring on beginning teacher turnover? American Educational Research Journal, 41(3), 681-714.

Soba, M., Babayiğit, A., \& Demir, E. (2017). Yaşam doyumu ve tükenmişlik; Öğretmenler üzerine bir araştırma. Mehmet Akif Ersoy Üniversitesi, Sosyal Bilimler Enstitüsü Dergisi, 9(19), 269-286.

Togia, A., Koustelios, A. and Tsigilis, N. (2004). Job satisfaction among Greek academic librarians. Library \& Information Science Research, 26(3), 373-383.

Toprak, E., (2013). Mesleki tükenmişlik düzeyi ile iş tatmini arasındaki iliş̧ki: Sağlık sektöründe bir araştırma (Unpublished master's thesis). Niğde Üniversitesi, Sosyal Bilimler Enstitüsü, Niğde.

Tschannen-Moran, M., \& Barr, M. (2004). Fostering student learning: The relationship of collective teacher efficacy and student achievement. Leadership and Policy in Schools, 3(3), 189-209.

Ünal, A. (2015). İ̧ doyumu, yaşam doyumu ve yaşam anlamı değişkenlerinin ilkokul ve ortaokul öğretmenlerinin mesleki bağlılıkları üzerine etkisi (Unpublished master's thesis). Ondokuz Mayıs Üniversitesi Eğitim Bilimleri Enstitüsü. 
Vecchio, R. P. (1988) Organizational behavior. Chicago: Dryden Press.

Ware, H., \& Kitsantas, A. (2007). Teacher and collective efficacy beliefs as predictors of professional commitment. The Journal of Educational Research, 100(5), 303-310.

Watts, G. J. (2013). Relationship among self-efficacy, social support, job satisfaction, and teacherrelated burnout (Doctoral dissertation). Northcentral University Behavioral and Health Sciences, Arizona.

Wei, O. P., \& Abdullah, A. G. K. (2016). Burnout and job satisfaction among teachers in Chinese independent secondary school. International Journal of Elementary Education, 5(5), 47-50.

Weiss, D. J., Dawis, R. V., \& England, G. W. (1967). Manual for the Minnesota Satisfaction Questionnaire. Minnesota Studies in Vocational Rehabilitation, 22, 120.

Zaccaro, S. J., Blair, V., Peterson, C., \& Zazanis, M. (1995). Collective efficacy. In J. E. Maddux (Ed.), Self-efficacy, adaptation, and adjustment: theory, research, and application (pp. 305-328). New York: Plenum Press.

Zafer Güneş, D. (2014). ilköğretim okulu öğretmenlerinin örgütsel güven ve kolektif yeterlik algıları ile örgütsel farkındalık düzeyleri arasındaki ilişkilerin incelenmesi (Unpublished doctoral dissertation). Abant İzzet Baysal Üniversitesi Eğitim Bilimleri Enstitüsü, Bolu.

\section{Biografical Notes:}

Dr. Mevlut AYDOGMUS, PhD, Assistant Professor for Curriculum and Instruction Department of Ahmet Kelesoglu Education Faculty of Necmettin Erbakan University in Konya, Turkey. His field of research is pedagogical practice, curriculum development, characteristics of teacher candidates.

Dr. Huseyin SERCE, PhD, Assistant Professor for Department of Curriculum and Instruction at Selçuk University, Faculty of Education. Among his research interests are learning and teaching methodology, action research, and teacher education. 